\title{
PENGELOLAAN PEMBELAJARAN AKIDAH AKHLAK DI MADRASAH ALIYAH NEGERI KOTA MAGELANG
}

\author{
Hilmawan Nur Ramadhan, Pujiriyanto \\ Jurusan Kurikulum dan Teknologi Pendidikan, FIP UNY \\ e-mail: hilmawan.nur2015@student.uny.ac.id, pujiriyanto@uny.ac.id
}

\begin{abstract}
Abstrak
Penelitian ini bertujuan untuk mendeskripsikan kegiatan pengelolaan pembelajaran akidah akhlak dan faktor-faktor yang pendukung menghambat pelaksanaannya. Penelitian menggunakan pendekatan kualitatif, jenis deskriptif. Sumber data penelitian yaitu kepala sekolah, 3 guru mata pelajaran akidah akhlak kelas X dan XI, siswa kelas X dan XI. Metode pengambilan data menggunakan teknik wawancara, observasi, dan dokumentasi. Instrumen penelitian adalah peneliti sendiri sebagai human instrument. Keabsahan data diperoleh melalui triangulas sumber dan teknik. Hasil penelitian menunjukkan kegiatan pengelolaan pembelajaran yang dilakukan terbagi menjadi 3 yaitu perencanaan dengan aktivitas menyusun RPP, bahan ajar, dan media pembelajaran, Pelaksanaan meliputi kegiatan pendahuluan, inti dan penutup. Kegiatan pendahuluan meliputi apersepsi, pre-test, menyampaikan tujuan pembelajaran, memberi nasihat. Kegiatan inti sesuai denganmodel yang diterapkan didominasi oleh problem based learning, CTL, dan model kooperatif. Metode bervariasi didominasi ceramah, diskusi, presentasi dan tanya jawab dengan menerapkan strategi bervariasi dengan dukungan media berbasis visual. Penutup berisi kegiatan menyimpulkan secara lisan dan tertulis, dan memberikan feedback kepada siswa. Evaluasi sayangnya masih berbasis ujian tertulis dan lisan, dengan evaluasi formatif yang dilakukan secara terjadwal. Hambatan yang terjadi yaitu adanya kekurang fasilitas media pembelajaran yang kurang tersedia, sementara faktor pendukung adanya motivasi dari pada guru untuk berinovasi..
\end{abstract}

Kata Kunci: Pengelolaan Pembelajaran, Akidah Akhlak, Madrasah Aliyah.

\begin{abstract}
This study aims to describe the activities of the lerning management of moral learning and the factors that were support and hinder on its implementation. Research used a qualitative approach. Sources of research data were the principal, 3 teachers of moral subjects of class X and XI,and the students were in class X and $X I$. The collected by interview, observation, and documentation. The research instrument was the researcher himself as a human instrument. Credibility of data was achieved tgrough triangulation sources and tecniques The results showed that the learning management activities carried out were divided into 3 namely planning with the activities of preparing lesson plans, teaching materials, and learning media. Implementation included preliminary, core and closing activities. Preliminary activities include apperception, pre-test, conveying learning objectives, giving advice. The core activities in accordance with the applied model are dominated by problem based learning, CTL, and cooperative models. The varied methods are dominated by lectures, discussions, presentations and questions and answers by implementing varied strategies with the support of visual based media. Closing contains concluding activities verbally and in writing, and giving feedback to students. The evaluation is unfortunately still based on written and oral examinations, with formative evaluations conducted on a scheduled basis. Barriers that occur are the lack of learning media facilities that are not available, while supporting factors are the motivation of the teacher to innovate.
\end{abstract}

Keywoards: Learning Management, Moral Aqeedah, Madrasah Aliyah.

\section{PENDAHULUAN}

Undang Undang Republik Indonesia Nomor 20 Tahun 2003 tentang Sistem Pendidikan Nasional pasal 1 ayat 1 menjelaskan bahwa Pendidikan sebagai usaha sadar dan terencana untuk mewujudkan suasana belajar dan proses pembelajaran agar peserta didik secara aktif mengembangkan potensi dirinya untuk memiliki kekuatan spiritual keagamaan, pengendalian diri, kepribadian, kecerdasan, akhlak mulia, serta keterampilan yang diperlukan dirinya, masyarakat, bangsa, dan Negara. Menurut Hasan (2003: 41) Pendidikan tidak hanya menggarap akal saja, melainkan menggarap seluruh bagian-bagian jiwa yang meliputi rasa, akal, kehendak, ingatan, dimana isi jiwa serta manifestasi isi jiwa ke dalam bicara, sikap, tingkah laku, pernuatan, dan kegiatan. Pendidikan itu suatu kegiatan merubah dan membentuk individu menjadi bercorak diri yang bernilai tinggi. 
Tujuan pendidikan pada Undang Undang Republik Indonesia Nomor 20 Tahun 2003 tentang Sistem Pendidikan Nasional bab 2 pasal 3 yaitu Mengembangkan kemampuan dan membentuk watak serta peradaban bangsa yang bermartabat dalam rangka mencerdaskan kehidupan bangsa, bertujuan untuk berkembangnya potensi peserta didik menjadi manusi yang beriman dan bertakwa kepada Tuhan Yang Maha Esa, berakhlak mulia, sehat, berilmu, cakap, kreatif, mandiri, dan menjadi warga yang demokratis serta bertanggung jawab.

Gordon dalam Aunurrahman (2016: 4) dalam proses pembelajaran, pengembangan potensi-potensi siswa harus dilakukan secara menyeluruh dan terpadu. Pengembangan potensi siswa secara tidak seimbang pada gilirannya menjadikan pendidikan cenderung lebih peduli pada pengembangan satu aspek kepribadian tertentu saja, bersifat partikular dan parsial. Padahal sesungguhnya pertumbuhan dan perkembangan siswa merupakan tujuan yang ingin dicapai oleh semua sekolah dan guru, dan itu berarti sangat keliru jika guru hanya bertanggung jawab menyampaikan materi pelajaran pada bidang studinya saja.

Selain itu, Gagne, Briggs \& Wager dalam Rusmono (2014: 6), pembelajaran adalah serangkaian kegiatan yang dirancang untuk memungkinkan terjadinya proses pembelajaran. "Instruction is set of event that effect learners in such a way that learning is facilitated".

Pengelolaan pembelajaran menurut Suryosubroto (2002: 19) yaitu proses belajar mengajar meliputi kegiatan yang dilakukan guru mulai dari perencanaan, pelaksanaan kegiatan sampai evaluasi dan program tindak lanjut yang berlangsung dalam situasi edukatif untuk mencapai tujuan tertentu yaitu pengajaran.

Jarolemek \& Foster dalam Suryosubroto (2002: 18) mendefinisikan bahwa mengajar mengandung tiga peranan besar yaitu planning for learning and instruction, fasilitatory of learning and evaluation of learning. Hal ini berartika bahwa pembelajaran merupakan cara yang digunakan oleh guru, perancang materi, spesialis kurikulum dan mempromosikan pembelajaran. Pengelolaan pembelajaran merupakan proses pembelajaran utuh dan menyeluruh yang dimulai dari perencanaan dan pelaksanaan hingga evaluasi pembelajaran, termasuk evaluasi programnya dalam rangka mencapai tujuan pendidikan yang telah ditentukan (Daryanto, 2013: 312).

Berdasarkan pernyataan di atas diungkapkan bahwa pengelolaan pembelajaran dibagi menjadi 3 kegiatan yaitu:

1. Perencanaan Pembelajaran

Johnson dalam Suryosubroto (2002: 27) mengatakan bahwa:

"teacher are expected to design and deliver instruction so that student learning facilitated. Instruction is asset of event design to initiated activated, and support learning situation (including the classroom, the student, and the curriculum materials) so that learning facilitated".

Hal ini berartikan bahwa guru diharapkan untuk merancang dan menyampaikan instruksi sehingga pembelajaran peserta didik akan terasa efektif. pembelajaran merupakan suatu kegiatan yang direncanakan untuk menyampaikan materi dan mendorong minat belajar peserta didik (tediri atas situasi kelas, peserta didik, dan materi pembelajaran) sehingga menciptakan pembelajaran yang efektif dan efisien.

Sudjana (2005: 53) mengatakan bahwa pada saat perencanaan pembelajaran, pendidik perlu melakukan persiapan yang meliputi mengenali karakteristik peserta didik; menyiapkan bahan dan strategi pembelajaran, menggandakan bahan pembelajaran, menyiapkan fasilitas dan alat bantu, mempelajari jadwal pembelajaran, dan memeriksa kembali langkah-langkah persiapan tersebut. Hal ini sependapat dengan Majid (2012) mengatakan bahwa perencanaan dapat diartikan proses penyusunan materi, penggunaan media pengajaran, penggunaan pendekatan dan metode pengajaran, dan 
penilaian dalam suatu alokasi waktu yang akan dilaksanakan pada masa tertentu untuk mencapai tujuan yang telah ditentukan.

\section{Pelaksanaan Pembelajaran}

Surachmad dalam Suryosubroto (2002:

36) mengatakan bahwa pelaksanaan pembelajaran adalah proses berlangsungnya belajar mengajar di kelas yang merupakan inti dari kegiatan pendidikan sekolah. Hal ini serupa dengan pernyataan dari Suryosubroto (2002: 36) mengatakan bahwa pelaksanaan pembelajaran adalah interaksi guru dengan murid dalam rangka menyampaikan bahan pelajaran kepada peserta didik dan untuk mencapai tujuan pembelajaran.

Majid (2012: 104) bahwa tahapantahapan dalam kegiatan pembelajaran meliputi: kegiatan awal, melaksanakan apersepsi atau penilaian kemampuan, menciptakan kondisi awal pembelajaran, kegiatan inti dan penutup.

\section{Evaluasi Pembelajaran}

Hamalik (2008: 210) bahwa evaluasi pembelajaran adalah suatu proses berkelanjutan tentang pengumpulan dan penafsiran informasi untuk menilai (assess) keputusan-keputusan yang dibuat dalam merancang suatu sistem pengajaran. Sedangkan evaluasi pembelajaran adalah dalam tercapai tidaknya tujuan pendidikan dan pengajaran perlu dilakukan usaha tindakan atau kegiatan untuk menilai hasil belajar (Suryosubroto, 2002: 53).

Berdasarkan rumusan dalam proses evaluasi, Hamalik (2008: 210) menyatakan bahwa ada tiga implikasi yaitu : pertama, evaluasi adalah suatu proses yang terusmenerus, bukan hanya pada akhir pengajaran, tetapi dimulai sebelum dilaksanakannya pengajaran sampai dengan berakhirnya pengajaran; kedua, proses evaluasi senantiasa diarahkan ke tujuan tertentu, yakni untuk mendapatkan jawaban-jawaban tentang bagaimana memperbaiki pengajaran; ketiga, proses evaluasi menuntut penggunaan alat-alat ukur yang akurat dan bermakna untuk mengumpulkan informasi yang dibutuhkan guna membuat keputusan. Dengan demikian, evaluasi merupakan proseesn yang berkenan dengan pengumpulan informasi yang memungkinkan kita menentukan tingkat kemajuan pengajaran dan memanfaatkan waktu pembelajaran sebaik-baiknya.

Hamalik \& Suryosubroto sepakat bahwa proses penilaian evaluasi terbagi menjadi 4 yakni :

1). Evaluasi formatif

Evaluasi formatif adalah penialaian yang dilakukan guru setelah satu pokok bahasan selesai dipelajari oleh peserta didik. Dengan kata lain bahwa evaluasi formatif untuk memperbaiki kesulitan peserta didik terhadap penerimaan materi yang telah disampaikan oleh guru.

2). Evaluasi sumatif

Evaluasi sumatif diselenggarakan oleh guru pada jangka waktu tertentu, hal ini dilakukan untuk mengetahui seberapa besar keberhasilan belajar peserta didik.

3). Pelaporan hasil penilaian

Setelah adanya evaluasi sumatif maupun formatif maka setiap guru mengolah nilai akhir peserta didik dan dimasukkan kedalam buku raport peserta didik. Hal ini biasanya terjadi saat akhir semeseter.

4). Melakukan evaluasi diagnostik

Evaluasi diagnostik berartikan bahwa membantu peserta didik terhadap kesulitan belajar. Evaluasi ini berupa perbaikan penilaian pembelajaran peserta didik. Sehingga peserta didik yang menerima hasil akhir kurang baik bahkan di bawah rata-rata maka, guru melakukan perbaikan dengan memberikan ulangan atau soal-soal perbaikan belajar peserta didik.

Menurut Kamus Besar Bahasa Indonesia (2005: 377), tertulis bahwa guru adalah orang yang pekerjaannya (mata pencahariannya, profesinya) mengajar. Berdasarkan definisi KBBI tersebut dapat diartikan bahwa definisi guru masih belum jelas dan masih sulit untuk dimengerti. Hal ini juga disampaikan oleh Suparlan (2005: 4) guru adalah seseorang yang diangkat secara resmi oleh pemerintah atau lembaga swasta dengan surat keputusan yang memberikan tugas dan fungsi kepada seseorang 
guru di Sekolah Dasar, atau Sekolah Menengah Pertama, atau disatuan pendidikan lainnya.

Menurut Undang-Undang Republik Indonesia Nomor 20 Tahun 2003 tentang Sistem Pendidikan Nasional Pasal 39 ayat 2 menyatakan bahwa Pendi dik merupakan tenaga profesional yang bertugas merencanakan dan melaksanakan proses pembelajaran, menilai hasil pembelajaran, melakukan pembimbingan dan pelatiha, serta melakukan penelitian dan pengabdian kepada masyarakat, terutama bagi pendidik pada perguruan tinggi. Guru adalah orang yang merencanakan pembelajaran. pelaksana pembelajaran, mengevaluasi pembelajaran. Sebagai perencana, guru harus mempertimbangkan secara sungguh-sungguh segala sesuatu yang akan dilaksanakan dalam pembelajaran (Yuliantoro, 2015: 1-2).

Hadari Nawawi dalam Suryosubroto (2002: 7), mengatakan bahwa guru sebagai pengelola pembelajaran yaitu:

1). Mempelajari materi pengajaran, yang akan dijadikan tuntunan dalam penyusunan rencana pelajaran.

2). Memilih pendekatan atau strategi untuk menyampaikan.

3). Memillih alat-alat pelajaran dan sarana lain.

4). Memilih strategi evaluasi yang akan diambil.

Al-Banna (1983: 13) mengatakan bahwa akidah adalah sesuatu yang mengharuskan hati anda membenarkannya, yang membuat jiwa anda tenang tentram kepadanya dan menjadi kepercayaan anda yang bersih dari kebimbingan atau keraguan. Sedangkan menurut Al-Jazairi (1994: 30) mengatakan bahwa aqidah merupakan ketentuan atau ketetapan Allah yang fitrak selalu bersandar kepada kebenaran (haq), sah selamanya dan terikat ke dalam hati.

Menurut Amin dalam Asmaran (1994: 4) akhlak adalah kebiasaan kehendak. Hal ini berartikan bahwa kehendak yang dilakukan terus-menerus dan diterapkan kedalam kehidupan sehari-hari maka itu disebut akhlak. Sedangkan, menurut Al-Wasit dalam Asmaran (1994: 4) akhlak ialah sifat yang tertanam dalam jiwa, yang dengannya lahirlah macammacam perbuatan baik atau buruk, tanpa membutuhkan pemikiran dan pertimbangan.

Peraturan Menteri Agama RI Nomor 2 tahun 2008 tentang Standar Kompetensi Lulusan dan Standar Isi Pendidikan Agama Islam dan Bahasa Arab di Madrasah BAB VIII butir B, bahwa tujuan pembelajaran Akidah Akhlak Madrasah Aliyah yaitu: pertama, menumbuh kembangkan akidah melalui pemberian, pemupukan, dan pengembangan pengetahuan, penghayatan, pengalaman, pembiasaan, serta pengalaman peserta didik tentang akidah Islam sehingga menjadi manusia muslim yang terus berkembang keimanan dan ketakwaannya kepada Allah SWT; kedua, mewujudkan manusia dalam kehidupan maupun sosial, sebagai manifestasi dari ajaran dan nilai-nilai akidah islam.

Menurut Raji dalam Sudrajat (2016: 133) menjelaskan tahapan yang dapat ditempuh untuk menanamkan keimanan yang fungsional untuk menghiasi hati ada tiga yaitu: pertama, pada setiap kesempatan anak diarahkan memperhatikan keagungan Allah melalui penciptaan-Nya. Dalam berbagai kesempatan bersama dengan anak baik di darat, gunung, maupun pantai, gunakanlah kesempatan ini untuk mengajak anak memperhatikan keagungaan penciptaan-Nya; kedua, menjelaskan kemahakuasaan Allah Swt. Dalam kesempurnaan menciptakan manusia, hewan, tumbuhan dan makhluk lainnya. Anak perlu dijelaskan agar lebih meyakini kegungan Allah melalui kesempurnaan penciptaan-Nya; ketiga, menanamkan ketauhidan, dengan menggunakan cara-cara yang telah dirumuskan para syaikhul Islam. Penanaman tauhid adalah agar anak tumbuh rasa cintanya yang paling besar hanya kepada Allha Swt. Dengan cara menunjukkan kasih sayang Tuhan dengan berbagai media yang dapat sebagai bukti bahwa kasih sayang Tuhan adalah yang paling tinggi.

Hasil penelitian Rilin Widia Safitri (2015) menyimpulkan proses pengelolaan pembelajaran akidah akhlak di MAN 2 Surakarta, sehingga muncul penemuanpenemuan mengenai pengelolaan pembelajaran yang efektif dimulai dari perencanaan, 
pelaksanaan, maupun evaluasinya, dan juga faktor penghambat maupun pendukung dalam proses pengelolaan pembelajaran.

Berdasarkan hasil Observasi di MAN 1 Kota Magelang diperoleh data mengungkapkan bahwa sekolah ini menjadi objek sampel sekolah setara madrasah aliyah se-Jawa Tengah. Sekolah ini memiliki prestasi dan akreditasi yang memuaskan. Berdasarkan hasil pengamatan awal mengungkapkan bahwa proses pembelajaran yang dilaksanakan di MAN 1 Kota Magelang masih terbilang kurang efektif, dikarena guru kurang memperhatikan media pembelajaran, guru hanya menggunakan buku paket dan LKS untuk kegiatan pembelajaran.

\section{METODE PENELITIAN}

Penelitian ini menggunakan pendekatan kualitatif jenis penelitian deskriptif. Seting penelitan di MAN 1 Kota Magelang Tegowanon, Payaman, Kec. Secang, Magelang, Jawa Tengah. Sumber data penelitian adalah kepala sekolah, guru mata pelajaran akidah akhlak kelas X dan XI, siswa kelas X dan XI. Selain itu proses pembelajaran. Teknik pengumpulan data menggunakan wawancara, sobservasi dan studi dokumen. Keabsahan data diperole melalui triangulasi sumber dengan membandingkan data dari berbagai sumber. Data hasil wawancara dibandingkan dengan data hasil observasi Teknik analisis data mengunakan analisis interaktif. Data tersebut dideskripsikan, kemudian dikategorikan berdasarkan kesamaan, perbedaan dan yang spesifik dari sumber. Dan selanjutnya data dianalisis akan menghasilkan kesimpulan. Sugiyono (2015: 335) mengatakan analisis data adalah proses mencari dan menyusun secara sistematis data yang diperoleh dari hasil wawancara, catatan lapangan, dan dokumentasi, dengan cara mengorganisasikan data kedalam kategori, menjabarkan ke dalam unit-unit, melakukan sintesa, menyusun kedam pola, memilih mana yang penting dan yang akan dipelajari, dan membuat kesimpulan sehingga mudah dipahami oleh diri sendiri maupun orang lain. Menurut Miles dan Huberman dalam Sugiyono (2015: 337-345) model analisis data kualitatif terdapat tiga tahap yaitu data reduction, data display, dan data conclusing drawing.

\section{1) Data Reduction}

Teknik ini merujuk pada proses memilih, mengorganisasikan, mendeskripsikan dan mentransformasikan data yang mendekati keseluruhan dari hasil catatan-catatan lapangan, hasil wawancara, dokumentasi, dan materi empiris lainnya. Hal ini untuk mengambil kesimpulan data, memilih hal-hal pokok, disusun secara sistemati, sehingga memberikan penjelasan terkait pengelolaan pembelajaran Akidah Akhlak.

2) Data Display

Penyajian data bisa dilakukan dalam bentuk uraian singkat, bagan, hubungan antar katagori, flowchart dan sejenisnya. Melalui penyajian data maka data akan terorganisasikan, tersusun dalam pola hubungan. Kegiatan menyajikan data ini berfungsi untuk memudahkan dan memahami apa yang terjadi, merencanakan kerja selanjutnya berdasarkan apa yang telah dipahami. Penyajian data dalam penlitian ini memiliki tujuan untuk memudahkan peneliti dalam memahami hasil penelitian yang di dapat. Peneliti akan menyajikan dan menghubungkan data yang diperoleh dari observasi, wawancara dan dokumentasi yang telah direduksi menjadi sebuah narasi yang mudah untuk dipahami dengan tujuan untuk mengetahui langkah atau tindakan apa yang akan dilakukan selanjutnya.

3) Data Conclusing Drawing

Langkah ini merupakan untuk menarik kesimpulan dari hasil-hasil data selama di lapangan. Kesimpulan dalam penelitian kualitatif yang diharapkan adalah merupakan temuan baru yang sebelumnya belum pernah ada. Temuan dapat berupa deskripsi atau gambar suatu objek yang sebelumnya masih remang-remang atau gelap sehingga setelah diteliti menjadi jelas, dapat berupa hubungan kausal atau interaktif, hipotesis atau teori. 


\section{HASIL PENELITIAN DAN PEMBAHASAN}

\section{Hasil}

Hasil penelitian menyajikan data tentang proses pengelolaan pembelajaran akidah akhak di MAN 1 Kota Magelang.

\section{Pengelolaan Pembelajaran Akidah Akhlak}

Hasil penelitian mengungkapkan kegiatan pengelolaan pembelajaran akidah akhlak di MAN 1 Kota Magelang terdiri dari 3 kegiatan yaitu perencanaan, pelaksanaan, dan evaluasi.

\section{a. Perencanaan Pembelajaran}

Kegiatan perencanaan yang dilakukan oleh guru mata pelajaran akidah akhlak meliputi:

1. Penyusunan atau pengembangan RPP akhlak

Pengembangan RPP oleh guru pengampu mata pelajaran akidah akhlak MAN 1 masih mengarah ke tingkat kognitif dan psikomotor, namun belum mengarah ke segi afektif.

2. Menyusun bahan ajar

Bahan ajar didominasi oleh bahan ajar cetak berupa bahan ajar LKS (Lembar Kerja Siswa) dan buku paket sekolah. Artinya ditinjau dari segi fungsi bahan ajar masih diorientasikan untuk mendukung penyampaian materi. Bahan ajar lainnya belum begitu banyak dikembangkan.

3. Merencanakan media pembelajaran akidah akhlak

Guru akidah akhlak perencanaan media pembelajaran sudah memperhatikan karakteristik materi dan tujuan pembelajaran serta karakteristik peserta didik. Media pembelajaran yang direncanakan oleh guru mata pelajaran akidah akhlak efektif dan efisien. Selain itu mempertimbangan tujuan pembelajaran. Namun pertimbangan karakteristik siswa masih bersifat umum belum bisa mewadahi karakteristik per individu.

\section{b. Pelaksanaan Pembelajaran}

Berdasarkan hasil data sebelum pembeljaaran dimulai guru melakukan apersepsi kepada siswa untuk pengkondisan namun belum sepenuhnya didasari oleh keputusan pedagogis. Selain itu pretest dilakukan namun kurang efektif karena bersifat acak dan tidak bisa memperoleh gambaran menyeluruh siswa. merasa tertinggal atau merasa kesulitan.

Guru mata pelajaran akidah akhlak pada awal kegiatan pembelajaran sudah menjelaskan tujuan pembelajaran kepada siswa sayangya tujuan masih berorietasi kognitif dan sudah bersifat kontekstual. Guru telah memberikan gambaran penerapan sehari-hari. Orietasi kognitif sebenarnya tidak sesuai dengan aspek terminal atau tingkah laku yang diungkapkan

Terkait dengan motivasi guru memberikan motivasi kepada siswa dengan secara lisan dalam bentuk nasehat, kata mutiara, serta penghargaan kepada siswa yang aktif di dalam kelas. Dberikan pla contoh-contoh tokoh teladan yang patut dicontoh oleh dalam kegiatan sehari-hari. Siswa merasa lebih terfokus.

Berkaitan dengan kegiatan inti penerapan model pembelajaran sudah sangat baik yaitu Problem Based Learning, Konstektual, dan Kooperatif menyesuaikan materi. Namun penerapan prinsip-prinsip analsiis psikologis masih kurang terutama berkaitan dengan karakteristik siswa.

Penerapan metode pembelajaran yang diterapkan ceramah, diskusi, presentasi, dan tanya jawab sebenarnya terlalu dominan dan kurang sesuai dengan model yang dipergunakan.. Metode problem based learning menyesuaikan materi pembelajaran dan karakteristik namun belum tercermin di dalam kegatan pembelajaran.

Penerapan strategi pembelajaran oleh guru mata pelajaran akidah adalah problem based learning, konstektual, dan kooperatif learning. Sayang tidak tercermin benar di dalam langkah-langkah padahal strategi ini 
merupakan skenario penting dalam mencapai tujuan pembelajaran.

Media pembelajaran yang digunakan oleh guru mata pelajaran akidah akhlak selama kegiatan pembelajaran yaitu buku paket, dan LKS yang masih mendominasi namun kurang meanfaatkan sumber belajar by utilization, Media pembelajaran sudah bervariasi hanya porsi sesuai dengan pendekatan ataupun model yang dipilih belum sesuai.

Guru mata pelajaran akidah akhlak melakukan kegiatan merangkum isi materi pembelajaran secara lisan dan dirasa kurang efektif. Keraf dalam Desrina (2013) bahwa tujuan menulis ringkasan yaitu, membuat ringkasan untuk mengembangkan ekspresi serta penghematan kata. Ringkasan akan mempertajam daya kreasi dan konsentrasi. Jadi bukan sekedar dilakukan secara lisan tanpa partisipasi siswa.

Berkaitan dengan umpan balik secara langsung dengan metode penyampaian lisan dan tertulis. Hal ini di lakukan oleh guru bagi siswa yang aktif di dalam kelas sehinga sebbenarnya kuran tepat. Feedback seharusnya mendasarkan kepada hasil yang diperoleh atau dicapai oleh siswa. Umpan balik harusnya berkontribuasi kepada seluruh siswa namun juga proses pembelajaran.

\section{c. Evaluasi Pembelajaran}

Model evaluasi yang dilakukan guru juga masih bersifat rutin sesuai ola seperti biasanya. Evaluasi sudah mencakup evaluasi formatif maupun sumatif yang disertai remedial dan pengayaan. Model evaluasi belum mengarah proses dan sesuai dengan model pembelajaran PBL, kontekstual dan kooperatif yang bersifat student center.

\section{Faktor Penghambat dan Pendukung Pengelolaan Pembelajaran Akidah Akhlak}

\section{a. Faktor Pendukung}

Pendukung kegiatan pembelajaran akhlak dan akidah dari internal adanya sikap sikap aktif siswa, sikap efektif guru dan kurikulum yang fleksibel. Pendukung dari eksternal adanya fasilitas pembelajaran, sumber belajar, dan lingkungan sekolah yang memadai.

\section{b. Faktor Penghambat}

Faktor yang menghambat kegiatan pengelolaan pembelajaran karena fasilitas untuk penerapan media masih terbatas dan waktu pembelajaran serta kondisi siswa yang seringkali mengantuk. Kondisi ini diakibatkan oleh tidak maksimalnya mediamedia yang berbasis visual dan menarik untuk disajikan karena keterbatasan fasilitas dan kondisi.

\section{Pembahasan}

Berdasarkan langkah-langkah yang ditempuh guru sebenarnya sudah sesuai standar pelaksanaan pembelajaran namun kreativitas guru untuk medesain aktivitas pembelajafran sesuai dengan kondisi dan kebutuhan masih kurang. Artinya aktivitas rutin lebih mengendalikan kegiatan dan tindakan guru

Berkenaan dengan penyusunan RPP ini selaras dengan pernyataan Wahyuni dan Ibrahim (2012: 69), Rencana Pelaksanaan Pembelajaran (RPP) merupakan perencanaan jangka pendek untuk memperkirakan tindakan yang akan dilakukan dalam kegiatan pembelajaran. Rencana pembelajaran perlu dilakukan untuk mengkoordinasikan komponen-komponen pembelajaran, yakni: kompetensi dasar, materi pokok, indikator, dan penilaian berbasis kelas. Namun orientasi kognitif seringkali menjebak karena adanya orientasi jangka pendek sehingga nuansa skolastik akademik masih dominan daripada pengembangan keterampilan proses.

Variasi bahan ajar nampaknya juga masih menjadi kendala karena keterampilan dan kecukupan waktu. Bahan ajar masih beorientasi LKS dan bentuk cetak. Majid (2012: 174) menyatakan bentuk bahan ajar setidaknya dapat dikelompokkan menjadi empat yaitu: 1) Bahan cetak (printed) antara lain handout, buku, modul, lembar kerja siswa, brosur, foto/gambar. 2) Bahan ajar dengar (audio) seperti kaset, radio, piringan hitam, dan compact disk audio. 3) Bahan ajar pandang 
dengar (audio visual) seperti video compact disk, film. 4) Bahan ajar interaktif (interactive teaching material) seperti compact disk interaktif.

Berkaitan dengan kegiatan guru di awal pembelajaran Hal ini selaras dengan Chatib dalam Wijaya (2015) bahwa menit-menit pertama dalam proses belajar adalah waktu yang terpenting untuk satu pembelajaran selanjutnya. Pada menit-menit pertama itulah apersepsi bisa dilakukan.

Guru akidah akhlak perencanaan media pembelajaran sudah memperhatikan karakteristik materi dan tujuan pembelajaran serta karakteristik peserta didik. Media pembelajaran yang direncanakan oleh guru mata pelajaran akidah akhlak efektif dan efisien. Selain itu mempertimbangan tujuan pembelajaran. Namun pertimbangan karakteristik siswa masih bersifat umum belum bisa mewadahi karakteristi per individu.

\section{a. Pelaksanaan Pembelajaran}

Berdasarkan hasil data penelitian mengungkapkan bahwa kegiatan pelaksanaan pembelajaran yaitu

1) Kegiatan Pendahuluan

a) Melakukan Apersepsi Kepada Siswa

Kegiatan ini dilakukan oleh guru secara lisan dan tanya jawab kepada siswa, metode penyampaian ini dilakukan pada awal kegiatan pembelajaran. Pengkondisian siswa nampaknya belum menjadi orientasi namun sebatas rutinitas. Artinya tidakan belum didasari keputusan pedagogis, namun guru secara rutin melakukannya. Guru sudah memiliki kesadaran arti pentingnya awal pelajaran bagi keberlanjutan perhatian siswa pada pelajaran berikutnya.

b) Melakukan Pre-test Kepada Siswa

$$
\text { Kegiatan Pre-test yang }
$$

dimaksudkan untuk mengetahi kesiapan siswa dan pengetahuan awal siswa. Kegiatan dilakukan guru melalui metode penyampaian lisan dan tanya jawab kepada siswa. Tanya jawab dilakukan dengan menunjuk siswa secara random. Guru memberikan alasan kegiatan ini untuk memastikan siswa siap mengikuti pembelajaran. Namun, kegiatan kurang efektif, dikarenakan pemilihan acak siswa belum tentu bisa memastikan kesiapan keseluruhan keseluruhan kemampuan siswa. Akibatnya siswa yang tidak teridentifikasi menjadi kurang aktif dalam kegiatan pembelajaran.

Sudijono dalam Effendy (2016) pre-test atau tes awal yaitu tes yang dilaksanakan dengan tujuan untuk mengetahui sejauh manakah materi atau bahan pelajaran yang akan diajarkan telah dapat dikuasai oleh siswa.

c) Menjelaskan tujuan pembelajaran

Guru mata pelajaran akidah akhlak pada awal kegiatan pembelajaran menjelaskan tujuan pembelajaran kepada siswa, guru menjelaskan kepada siswa dengan menyertai manfaat dan contohcontoh kegiatan yang dapat diterapkan di lingkungan kehidupan sehari-hari dengan menyesuaikan materi yang akan dijelaskan kepada siswa. Hal ini tidak sesuai dengan aspek terminal atau tingkah laku yang diungkapkan oleh Menurut Hamalik dalam Hidayat (2015) tujuan pembelajaran adalah suatu deskripsi mengenai tingkah laku yang diharapkan tercapai oleh siswa setelah berlangsung pembelajaran.

d) Memberikan Motivasi Kepada Siswa

Guru mata pelajaran akidah akhlak memberikan motivasi kepada siswa dengan secara lisan. Motivasi yang diberikan berupa nasihat-nasihat, kata mutiara, nilai tambahan kepada siswa yang aktif di dalam kelas, dan memberikan contoh-contoh tokoh teladan yang patut dicontoh oleh dalam kegiatan sehari-hari.

Hal ini serupa dengan yang dikemukakan oleh Sanjaya dalam Emda (2017) bahwa fungsi motivasi untuk mendorong siswa beraktifitas dan sebagai pengarah. 
2) Kegiatan Inti

a) Model Pembelajaran

Guru mata pelajaran akidah akhlak dalam penyampain materi pembelajaran menerapkan model pembelajaran Problem Basid Learning, Konstektual, dan Kooperatif. Penerapan model pembelajaran yang dilakukan oleh guru menyesuaikan materi pembelajaran yang akan disampaikan kepada siswa dan karakteristik siswa.

Hal ini sejalan dengan pendapat Joyce and Weil dalam Rosyidah (2016) mengungkapkan bahwa model pembelajaran disusun berdasarkan berbagai prinsip-pronsip pembelajaran, teori-teori psikologis, sosiologis, analisis atau teori-teori yang mendukung lainnya.

b) Metode Pembelajaran metode pembelajaran yang diterapkan guru mata pelajaran akidah akhlak adalah ceramah, diskusi, presentasi, dan Tanya jawab. Pemilihan metode pembelajaran yang diterapkan oleh guru akidah akhlak MAN 1 Kota Magelang menyesuaikan materi pembelajaran yang akan dijelaskan dengan karakteristik siswa, sehingga siswa dapat berpartisipasi aktif di dalam kelas.

Hal ini sejalan dengan pendapat Hamzah dalam Nurfaidah (2018) mengungkapkan bahwa metode pembelajaran merupakan jalan yang digunakan oleh guru, yang dapat menjalankan fungsinya sebagai alat untuk mencapai tujuan pembelajaran.

c) Strategi Pembelajaran

Strategi pembelajaran yang diterapkan oleh guru mata pelajaran akidah adalah problem based learning, konstektual, dan kooperatif learning. Penerapan strategi pembelajaran yang dilakukan oleh guru mata pelajaran akidah akhlak selalu berbeda-beda, hal ini diterapkan dikarenakan menyesuaikan materi pembelajaran yang akan disampaikan kepada siswa dan menyesuaikan karakter siswa.
Hal ini sejalan dengan pendapat Uno dalam Amri dan Ratnawuri (2016) bahwa strategi pembelajaran merupakan hal yang perlu diperhatikan oleh guru dalam proses pembelajaran.

d) Media Pembelajaran

Media pembelajaran yang digunakan oleh guru mata pelajaran akidah akhlak selama kegiatan pembelajaran yaitu buku paket, dan LKS, Namun, masih ada media pembelajaran yang lainnya yang digunakan oleh guru mata pelajaran akidah akhlak seperti LCD, Alat Peraga, Video, Powerpoint, dan sebagainya.

Hal ini sependapat dengan Miarso dalam Mahnun (2012) mengungkapkan bahwa hal pertama yang harus dilakukan guru dalam penggunaan media secara efektif adalah mencari, menemukan dan memilih media yang memenuhi kebutuhan belajar anak, menarik minat anak, sesuai dengan perkembangan kematangan dan pengalamannya anak dan latar belakang pengalamannya serta kondisi mental yang berhubungan dengan usia perkembangannya.

3) Kegiatan Penutup

a) Merangkum Isi Materi

Guru mata pelajaran akidah akhlak melakukan kegiatan merangkum isi materi pembelajaran dengan secara lisan dan siswa menulis kembali materi yang disampaikan oleh guru, hal ini lakukan dikarenakan berharap setiap siswa dapat menyerap isi materi pembelajaran yang telah disampaikan oleh guru. Namun, ada guru yang hanya melakukan kegiatan ini dengan secara lisan.

Hal ini menyebabkan kegiatan merangkum pembelajaran menjadi kurang efektif, hal ini selaras dengan pernyataan Keraf dalam Desrina (2013) bahwa tujuan menulis ringkasan yaitu, membuat ringkasan untuk mengembangkan ekspresi serta penghematan kata. Ringkasan akan mempertajam daya kreasi dan konsentrasi. 
b) Memberikan Feedback Kepada Siswa guru mata pelajaran akidah akhlak melakukan Feedback kepada siswa secara langsung dengan metode penyampaian lisan dan tertulis. Hal ini di lakukan oleh guru bagi siswa yang aktif di dalam kelas, pernyataan aktif dapat diartikan bahwa siswa sering bertanya dan dapat menjawab beberapa pertanyaan yang diberikan oleh guru maupun siswa yang lainnya.

Hal ini sejalan dengan Hattie dan Timperley dalam sumarno (2016) mengungkapkan bahwa feedback memberikan kontribusi pada prosesproses pembelajaran sangat bergantung pada fokus balikan dan tingkatan yang dituju.

\section{b. Evaluasi Pembelajaran}

Berdasarkan hasil data penelitian mengungkapkan dapat diketahui bahwa guru mata pelajaran akidah akhlak melakukan bermacam-macam evaluasi yaitu evaluasi formatif yang berbentuk ujian lisan, dan ujian harian, sedangkan evaluasi sumatif yang berbentuk ujian tengah semester (UTS), ujian akhir semester (UAS), jika siswa belum memenuhi kriteria minimum (KKM) maka guru mata pelajaran akidah akhlak melakukan evaluasi yang berbentuk ujian remedial dan pengayaan. Namun, kegiatan evaluasi yang dilakukan oleh guru pada saat akhir pembelajaran yaitu evaluasi formatif, sedangkan evaluasi sumatifnya dilakukan dengan waktu tertentu atau sudah direncanakan.

Hal ini sejalan dengan Sujana dalam Fetrianto (2017) mengungkapkan bahwa tes formatif dilaksanakan pada saat berlangsungnya proses belajar mengajar, khususnya pada akhir pengajaran.

\section{Faktor penghambat dan pendukung a. Faktor Pendukung}

Bedasarkan hasil data penelitian mengungkapkan bahwa faktor-faktor yang mendukung kegiatan pengelolaan pembelajaran akidah akhlak di Madrasah Aliyah Negeri 1 Kota Magelang, dari segi internal yaitu sikap aktif siswa dalam kegiatan pembelajaran di dalam kelas, adanya tim guru yang efektif sehingga dapat memecahkan permasalahan pembelajaran dan mengembangkan kreatifitas guru, dan kurikulum yang sesuai, sedangkan dari segi eksternal yaitu fasilitas pembelajaran yang memadai, sumber belajar yang memadai, lingkungan sekolah yang efektif untuk kegiatan pembelajaran.

Hal ini sejalan dengan pendapat Slameto dalam Kurniawan (2017) bahwa faktor-faktor yang mempengaruhi belajar digolongkan menjadi dua golongan yaitu faktor intern dan faktor ekstren. Faktor intern merupakan faktor yang ada dalam diri individu yang sedang belajar, sedangkan faktor intern merupakan faktor yang ada di luar individu.

\section{b. Faktor Penghambat}

Berdasarkan hasil data penelitian mengungkapkan bahwa faktor yang menghambat kegiatan pengelolaan pembelajaran oleh guru mata pelajaran akidah akhlak di MAN 1 Kota Magelang yaitu keterbatasan fasilitas media pembelajaran yang berupa LCD, keterbatasan waktu mengajar, dan faktor rasa kantuk yang dialami oleh siswa diwaktu setelah istirahat.

Hal ini sejalan dengan Nawawi (1989: 130) bahwa dalam kegiatan pelaksanaan kelas akan ditemui berbagai faktor penghambat. Hambatan tersebut bisa datang dari guru sendiri, dari siswa, lingkungan keluarga ataupun faktor fasilitas.

\section{PENUTUP}

Berdasarkan hasil penelitian dan pembahasan pada bab selanjutnya, dapat ditarik kesimpulan kegiatan pengelolaan pembelajaran akidah akhlak meliputi perencanaan yang masih berorientasi kepada kognitf dan kurang pada segi afektif. Pelaksanaan pembelajaran melipui pendahuluan termasuk apersepsi, pre-test, menyampaikan tujuan pembelajaran dan meningkatkan motivasi siswa. Kegiatan inti sudah berusahamenerapkan student center yaitu problem based learning, konstektual dan 
kooperatif, metode pembelajaran yang diterapkan yaitu ceramah, diskusi dan presentasi, dan tanya jawab, strategi pembelajaran yang diterapkan oleh guru yaitu konstektual, kooperatif, dan problem based learning, penerapan strategi pembelajaran yang guru terapkan kepada siswa selalu berbedabeda, media pembelajaran yang digunakan oleh guru yaitu media visual dan audio-visual. Kegiatan Penutup dengan menrik kesimpulan namun belum efektif karena belum mengarah kepada pembentukan kreasi siswa. Evaluasi pembelajaran meliputi sumatif dan formatif serta ada remedial dan pengayaan namun perlu mengutamakan proses

Faktor pendukung terdiri dari faktor internal dan eksternal yang sebenarnya lebih bersifat faktor fisik dan fasilitas bukan pada motivasi dan semangat dari guru maupun siswa.

\section{UCAPAN TERIMAKASIH}

Penulis mengucapkan terimakasih kepada Jurusan Kurikulum dan Teknologi Pendidikan FIP UNY yang tela memfasilitasi penelitian dan memberikan bimbingan atas enulisan artikel ini.

\section{DAFTAR PUSTAKA}

Adam, S. \& Syastra, M. T. (2015). Pemanfaatan Media Pembelajaran Berbasis Teknologi Informasi Bagi Siswa Kelas X SMA Ananda Batam. CBIS Journal, 3 no 2, 2337-8794.

Al-Banna, H. (1983). Akidah akhlak, Cet II, penerj. Hasan Baidaie. Bandung: PT Alma'arif.

Al-Jazairi, A.J. Aqidah : Seorang Mukmin, penerj. Salim Bazemol. Solo: Pustaka Mantiq.

Amri, R.F., \& Ratnawuri, T. Pengaruh Penggunaan Strategi Pembelajaran Peningkatan Kemampuan Berfikir (SPPKB) Terhadap Hasi Belajar Kewirausahaan Siswa Kelas XI Semester Genap SMK Muhammadiyah 2 Metro T.P 2015/2016. ISSN:2442-4994, Vol.1 (2016), 46-54.Asmaran. (1994).
Pengantar Studi Akhlak. Jakarta: Raja Grafindo Persada.

Aurrahman. (2016). Belajar dan Mengajar. Bandung:Alfabeta.

Daryanto \& Syaiful, K. (2013). Pembelajaran Abad 21. Yogyakarta: GAVA MEDIA.

Desrina, I., Agustina, Thahar, H. E. Peningkatan Keterampilan Menulis Ringkasan Melalui Model Pembelajaran Kooperatif Tipe Jigsaw Siswa kelas VIII 7 SMP 1 Batusangkar. Jurnal Bahasa, Sastra dan Pembelajaran, Vol. 1, No. 3, Oktober 2013.

Effendy, I. Pengaruh Pemberian Pre-test dan Post-test Terhadap Hasil Belajar Mata Diklat HDW.DEV.100.2.A Pada Siswa SMK Negeri 2 Lubuk Basung. Jurnal Ilmiah Pendidikan Teknik Elektro. Vol 1 No. 2, Oktober 2016, 81-88.

Emda, A. Kedudukan Motivasi Belajar Siswa Dalam Pembelajaran. Lantanida Journal, Vol. 5 No. 2 (2017), 93-196.

Fetrianto, F. (2017). Penerapan Formative Summative Evaluation Model Dalam Penelitian Tindakan. Pendidikan Olahraga Pascasarjana UM [Versi Elektronik].

Hamalik, O. (2008). Perencanaan Pengajaran Berdasarkan Pendekatan Sistem. Jakarta: PT Bumi Aksara.

Hasan, A \& Mukti, A. (2003). Kapita Selekta Pendidikan Islam. Jakarta: Pedoman Ilmu Jaya.

Hasan, A. dkk. (2005). Kamus Besar Bahasa Indonesia (edisi 3). Departemen Pendidikan Nasional, Jakarta:Balai Pustaka.

Hidayat, S. (2015) Tujuan Pembelajaran Sebagai Komponen Penting dalam Pembelajaran. WI Madya BKD \& Diklat Provinsi NTB [versi elektronik].

Kaswara, I. (2017). Pengaruh Pemberian Apersepsi Kemampuan Dasar Matematika Terhadap Kemampuan Siswa Menyelesaikan Soal Keseimbangan Benda Tegar. Skripsi. Universitas Tanjungpura. Pontianak. 
Kurniawan, B., Wiharna, O. \& Perman, T. Studi Analisis Faktor-Faktor Yang Mempengaruhi Hasil Belajar Pada Mata Pelajaran Teknik Listrik Dasar Otomotif. Jurnal of Mechanical Engineering Education, Vol. 4, No. 2, Desember 2017.

Mahnun, N. MEDIA PEMBELAJARAN (Kajian terhadap Langkah-langkah Pemilihan Media dan Implementasinya dalam Pembelajaran). Jurnal Pemikiran Islam; Vol. 37, No. 1 Januari-Juni 2012.

Majid, A. (2012). Perencanaan Pembelajaran. Bandung: Rosda Karya.

Nawawi, H. (1989). Organisasi Sekolah dan Pengelolaan Kelas. Jakarta: Tema Baru.

Nurfaidah, Suprapta, \& Said. M. L. Peningkatan Hasil Belajar Dengan Menggunakan Metode Pembelajaran Student Team Learning Modification. Jurnal Pendidikan Fisika, Vol.6, No.1, Maret 2018

Peraturan Menteri Pendidikan Nasional RI Nomor 41 Tahun 2007. Tentang Standar Proses Untuk Satuan Pendidikan Dasar dan Menengah. Jakarta.

Rusmono. (2014). Strategi Pembelajaran dengan Problem Based Learning Itu Perlu : Untuk Meningkatkan Profesionalitas Guru, Cet. 2. Bogor: Ghalia Indonesia.

Rosyidah, U. Pengaruh Model Pembelajaran Kooperatif Tipe Jigsaw Terhadap Hasil Belajar Matematika Siswa Kelas VIII SMP Negeri 6 Metro. Jurnal SAP Vol. 1 No. 2. Desember 2016.
Sudjana. N. (2005). Dasar-dasar Proses Mengajar/Belajar Mengajar. Bandung:Sinar Baru Algensindo.

Sudrajat. A. dkk. (2016). DINUL ISLAM Pendidikan Agama Islam di Perguruan Tinggi Umum. Yogyakarta: UNY Press.

Sugiyono. (2015). Metode Penelitian Pendidikan. Bandung: Alfabeta.

Sumarno. Pengaruh Balikan (Feedback) Guru Dalam Pembelajaran Terhadap Motivasi dan Hasil Belajar Peserta Didik. Jurnal Ilmiah Pendidikan Pancasila dan Kewarnegaraan, th. 1, No. 2, Desember 2016.

Suparlan. (2005). Menjadi Guru Efektif. Cet I. Yogyakarta: Hikayat Publishing.

Suryosubroto. B. (2002). Proses Belajar Mengajar di Sekolah. Jakarta: PT Rineka Cipta.

Undang-Undang RI No. 20 Tahun 2003. Sistem Pendidikan Nasional (Sisdiknas). Jakarta: Sinar Grafika, 2003.

Wahyuni, S dan Ibrahim, Abd. S. (2012). Perencanaan Pembelajaran Bahasa Berkarakter. Malang: Refika Aditama.

Wijaya, A. (2015). Penerapan Variasi Kegiatan Apersepsi dan Pembelajaran Interactive Learning untuk Meningkatan Aktifitas Pembelajaran dan Kemampuan Pronunciation Mahasiswa dalam mata kuliah Pronunciation Practice., Vol 15 No. 3, 1-118, 1412-5889. 